\title{
Possible impact of the green economy requirements on the furniture industry development in Kaliningrad region
}

\author{
Irina Safonova, and Andrei Golubev \\ Immanuel Kant Baltic Federal University, A. Nevskogo Str., 14, 236016 Kaliningrad, Russia
}

\begin{abstract}
The article discusses the possible impact of the requirements of the "green economy" on the furniture industry development in Kaliningrad region. The main question posed in the article - whether furniture manufacturers from Kaliningrad region can withstand future changes related to the "green economy". The authors collected and examined data on the main factors affecting the Kaliningrad furniture industry earlier (changes in customs regulations) and now (impact of the COVID-19 pandemic). Along with the general analysis, the authors considered the manufacture of individual products. No sharper drop in the furniture manufacture for home use compared with the furniture manufacture for offices was found as a result. As vendors, component suppliers, and furniture manufacturers have formed a regional cluster, its role in overcoming current challenges was also examined. Taking into account the current situation, the authors come to a rather negative conclusion about the contribution of the Kaliningrad Association of Furniture Manufacturers to the general anti-crisis actions. The requirements of the "green economy" are expected to lead to a significant increase in capital expenditures for Kaliningrad furniture manufacturers. Taking into account the current problems caused by changes in customs regulations and the COVID-19 epidemic, Kaliningrad furniture manufacturers will not put these costs at the top of their priorities in the next $3-5$ years.
\end{abstract}

\section{Introduction}

The problem of sustainable development and the spread of the "green economy" (and circular economy) is becoming more and more urgent every year due to the depletion of the base of non-renewable resources, the growing contradictions between the rate of renewable resource recovery and consumption, the impoverishment of nature, the inaccessibility of resources for all segments of the population. The principles of the "green economy" are not yet clearly defined, but individual ideas and provisions are mentioned in documents, reports, speeches of politicians in various countries of the world. Experts and specialists of UNEP (United Nations Environment Programme) declare the goal of long-term socio-economic development based on the balance of human activity and the natural environment, on improving the quality of life of modern generations without harming future generations on the basis of nature conservation [1]. 
In the Russian Federation, the ideas of "green economy" development are not conceptually enshrined in a specific document, but they find support at the state and regional levels in strategies and laws, and in public opinion. [2].

In Kaliningrad region, since 2012, the Strategy of Social and Economic Development of the Kaliningrad region is being implemented, "the development of which took into account global development trends and experience of building a socially oriented society with a sustainable economy", "green economy". [3]

The furniture industry of Kaliningrad Region is one of the successful examples of using the advantages of the Special Economic Zone established by federal legislation. [4] In this regard, the question of the possibility of early adaptation of this manufacture sector to the requirements of the "green economy" is regular and relevant.

\section{Materials and methods}

When considering the impact of factors affecting the state of the regional industrial sector, appropriate sources should be used to take into account the peculiarities of location, economic development, history and object potential of the study.

The sources of information for writing this material were based on data from the territorial body of the Federal State Statistics Service in Kaliningrad region. Additional information on furniture industry state was taken from local Internet information resources and publications on the relevant topic. Information on goals, long-term and medium-term plans and activities for the development of "green economy" approaches were obtained from the Internet resources of the United Nations (environmental unit). [1] Standard methods of statistical data collection and processing were used to present information in a relevant form.

\section{Results and discussion}

Many industrial enterprises of Kaliningrad region have experienced various stressful factors in the last 10 years, which makes it difficult to implement the idea of developing the "green economy". This is reflected in the dynamics of manufacture indices for the type of economic activity "Manufacturing" (Table 1).

Table 1. Manufacture indices by type of the economic activity "Manufacturing" (as a percentage of the previous year), Kaliningrad region [5]

\begin{tabular}{|l|l|l|l|l|l|l|}
\hline Years & 2010 & 2011 & 2012 & 2013 & 2014 & 2015 \\
\hline Index & 130.2 & 168.3 & 103.2 & 101.4 & 113.7 & 91.2 \\
\hline Years & 2016 & 2017 & 2018 & 2019 & 2020 & 2016 \\
\hline Index & 101.5 & 102.4 & 106.6 & 101.2 & 93.8 & 101.5 \\
\hline
\end{tabular}

As can be seen from Table 1, the peak of industrial development occurred in 2011, when the growth rate of manufacture in Kaliningrad region was $168.3 \%$ in the economic activity "Manufacturing" compared to the previous year. From 2010 to 2014, the manufacture volume increased by more than 2 times (a total of 216.8\%). From 2015 to the present, the growth rate has been negative or insignificant. The total cumulative growth from 2015 to 2020 was minus $3.3 \%$.

This trend was typical for most types of manufacture. The furniture manufacture was no exception. This is demonstrated by the indicator of the volume of shipped goods of own manufacture, works and services by own forces by months for 2020 (see Table 2). 
Table 2. Shipped goods of own manufacture, works and services performed by own forces by economic activities of the full range of organizations of producers for 2020 by months, thousand rubles. [6]

\begin{tabular}{|l|r|r|r|r|}
\hline Month & \multicolumn{1}{l|}{ February } & \multicolumn{1}{l|}{ March } & \multicolumn{1}{l|}{ April } & \multicolumn{1}{l|}{ May } \\
\hline Manufacturing industries & $46,199.7$ & $43,468.4$ & 40,276 & 35,186 \\
\hline Furniture manufacture & $1,145.7$ & $1,003.3$ & 988.3 & 807 \\
\hline Month & June & July & November & December \\
\hline Manufacturing industries & $42,557.8$ & $44,792.6$ & $56,378.6$ & \multicolumn{1}{l|}{58,109} \\
\hline Furniture manufacture & 639.6 & 779.2 & $1,176.6$ & 1126.8 \\
\hline
\end{tabular}

A serious negative impact on the volume of furniture production was caused by changes in customs clearance rules for products shipped from Kaliningrad region to the territory of the Russian Federation. After the abolition of the relevant benefits [7], all enterprises focused on the manufacture of furniture supplied to other regions of Russia have undergone significant logistical and tax difficulties.

Another important negative factor was the COVID-19 epidemic. According to the results of February-December 2020, the total value of the reduction of the indicator of the volume of shipped products by furniture enterprises was 555.9 thousand rubles, which exceeded the total growth of the indicator by 18.9 thousand rubles. The highest value of the indicator fall was in May and June 2020, which coincides with the time frame of anti-epidemic measures to COVID -19.

The modern furniture industry in Kaliningrad region has gradually formed into a cluster, combining the production of end products, semi-finished products, supply of special equipment, furniture logistics, wholesale and retail trade in furniture. Whether such an organization of the furniture community can help it survive is problematic.

A large number of furniture manufacturing enterprises started to appear in Kaliningrad region in the 1990s (Maksik LLP - 1992, Lazurit -1996, InterDesign -1997, and many others). By 2021, the industry has hundreds of businesses, mostly small and microenterprises. Manufacture of furniture takes 4-5 positions by the main indicators characterizing the scale of activity in the industry of Kaliningrad region (Table 3 ). The share of furniture production by volume of shipped goods is $2.1 \%$, by number of employees $-6.9 \%$.

Table 3. Furniture manufacture in the structure of manufacturing industries in Kaliningrad region in $2019, \%[8]$

\begin{tabular}{|l|c|c|c|c|}
\hline & $\begin{array}{l}\text { Structure } \\
\text { of the } \\
\text { volume } \\
\text { of } \\
\text { shipped } \\
\text { goods }\end{array}$ & $\begin{array}{l}\text { Structure of } \\
\text { fixed assets of } \\
\text { large and } \\
\text { medium-sized } \\
\text { enterprises and } \\
\text { organizations }\end{array}$ & $\begin{array}{l}\text { Structure of } \\
\text { investments in } \\
\text { fixed capital from } \\
\text { all sources of } \\
\text { funding }\end{array}$ & $\begin{array}{l}\text { Structure of the } \\
\text { average number } \\
\text { of employees } \\
\text { employed in } \\
\text { enterprises and } \\
\text { organizations }\end{array}$ \\
\hline Manufacturing industries - total & 100 & 100 & 100 & 100 \\
\hline food production & 29.6 & 46.9 & 31 & 31 \\
\hline $\begin{array}{l}\text { manufacture of computers, } \\
\text { electronic and optical products }\end{array}$ & 3.3 & 5.3 & 3.8 & 6.6 \\
\hline $\begin{array}{l}\text { manufacture of motor vehicles, } \\
\text { trailers and semi-trailers }\end{array}$ & 47 & 3.2 & 31 & 6.3 \\
\hline $\begin{array}{l}\text { manufacture of other vehicles } \\
\text { and equipment }\end{array}$ & 2 & 8.4 & 9.9 & 11 \\
\hline furniture manufacture & $\mathbf{2 . 1}$ & $\mathbf{1 . 2}$ & $\mathbf{1 . 0 7}$ & $\mathbf{6 . 9}$ \\
\hline Other manufacture facilities & 16 & 35 & 23.23 & 40.2 \\
\hline
\end{tabular}


Currently, such well-known enterprises as Mebel'naya fabrika Interdizayn LLC, Manngroup LLC, Daedal LLC, Verona LLC, Lazurit LLC, Dallas LLC, Pragmatika LLC, Maxik LLC, Falco LLC are engaged in the furniture manufacture. According to the website of the Government of Kaliningrad region, the largest manufacture volumes are the enterprises MEBEL STIL LLC (Lazurit), Logistika LLC (Interdesign), Akvella Invest LLC, MAGO RUS LLC [9]

Semi-finished products producers include enterprises Pikom, Mann Group. Suppliers of special raw materials and particleboard are enterprises DSPlit, Mebelshchik, Baltlaminat. Suppliers of leather raw materials and textiles for the manufacture of furniture - Art Textile; glass - Eurosteklo, Steklotsentr; accessories - Mebelshchik, Baltlaminate.

Some types of furniture produced by enterprises of Kaliningrad region are presented in Table 4.

Table 4. Furniture manufacture in Kaliningrad region $[7,8]$

\begin{tabular}{|l|c|c|c|c|}
\hline & 2017 & 2018 & 2019 & 2020 \\
\hline $\begin{array}{l}\text { Seating furniture, mainly with a } \\
\text { wooden frame, thousand pieces. }\end{array}$ & 20.9 & 15.5 & 11.0 & 11.5 \\
\hline $\begin{array}{l}\text { Growth rate, in \% compared to the } \\
\text { previous year }\end{array}$ & - & 74.2 & 71 & 104.1 \\
\hline $\begin{array}{l}\text { Kitchen cabinets, for bedroom, dining } \\
\text { room and living room, thousand pcs. }\end{array}$ & 144.4 & 126.3 & 114.1 & 106.02 \\
\hline $\begin{array}{l}\text { Growth rate, in \% compared to the } \\
\text { previous year }\end{array}$ & - & 87.5 & 90.3 & 93 \\
\hline $\begin{array}{l}\text { Sofas, couches with a wooden frame, } \\
\text { transformed into beds, thousand pcs. }\end{array}$ & 6.3 & 6.1 & 6.1 & 6 \\
\hline $\begin{array}{l}\text { Growth rate, in \% compared to the } \\
\text { previous year }\end{array}$ & - & 96.8 & 100 & 98.4 \\
\hline Wooden beds, thousand pcs. & 49.5 & 41.4 & 36.6 & 25.3 \\
\hline $\begin{array}{l}\text { Growth rate, in \% compared to the } \\
\text { previous year }\end{array}$ & 41.5 & 57.6 & 52.9 & 44.7 \\
\hline $\begin{array}{l}\text { Kitchen tables, for dining room and } \\
\text { living room, thousand pcs. }\end{array}$ & - & 138.8 & 91.8 & 84.5 \\
\hline $\begin{array}{l}\text { Growth rate, in \% compared to the } \\
\text { previous year }\end{array}$ & & 83.6 & 88.4 & 69.1 \\
\hline
\end{tabular}

According to the results of 2017-2020, most types of goods show a drop in manufacture indicators: furniture for seats with a wooden frame by an average of $17 \%$; kitchen cabinets, for bedrooms and living rooms by $9.7 \%$; wooden beds by $19.6 \%$. The data presented do not indicate that the manufacture of furniture for home use decreased at a significantly different rate compared to the manufacture of office furniture. Not all furniture manufacturers withstood the impact of stressful factors and ceased their activities (for example, in August 2020, the well-known enterprise Fabrika mebeli 555 LLC ceased its activities) [10]. From this, apparently, we can draw a disappointing conclusion about the furniture cluster effectiveness of Kaliningrad region. Somewhat more easily, if this can be said, the impact of changes in customs regulations and restrictions due to COVID-19 were endured by large furniture companies. Small and medium-sized furniture companies had a much harder time.

Modern demands from the state, the public, and consumers make furniture manufacturers naturally move in the direction of the development of the "green economy". Finished products are covered with a plastic edge, for the manufacture of which waste-free technologies are used (Furniture Factory Pragmatika). The majority of Kaliningrad furniture makers use environmentally friendly materials in their manufacture, laminated chipboard that does not contain phenol, edge glue of the company Henkel (Furniture factory Pragmatika, 
Furniture factory Lazurit). Furniture manufacture technologies involve the use of environmentally friendly raw materials supplied by companies that comply with the requirements of ISO 14000 , ISO 14001 . Waste from manufacture activities is efficiently disposed of.

\section{Conclusions}

Kaliningrad furniture manufacture, which received certain advantages in the initial stage of its development, experienced serious difficulties due to changes in the customs rules for the export of products to the territory of the Russian Federation and the COVID-19 pandemic.

Despite the difficulties created by the COVID-19 epidemic, there are furniture enterprises in Kaliningrad region that follow the advice about a balanced attitude towards the surrounding community. [11] Nevertheless, expansion of requirements and approaches of the "green economy" to the most part of furniture enterprises of Kaliningrad region will require significant financial investments from small and medium enterprises, which experienced the impact of the above described negative factors. From this point of view, the next 3-5 years will most likely take them to restore their pre-crisis economic condition, taking into account the increasing competition from enterprises from other regions of Russia.

On the other hand, this situation can be used for a radical renovation of manufacture and logistics in accordance with the requirements of the "green economy". This will certainly require financial assistance from regional and federal authorities.

\section{References}

1. United Nations Environmental Protection Unit, https://www.unep.org/ru/programma

2. N.M. Antonova, E.V. Kruglova, O.V. Ananieva, Bulletin of the Yekaterinburg Institute, 1(49), 29 (2020)

3. Resolution of the Government of Kaliningrad region dated August 2, 2012 No. 583 "On the Strategy of socio-economic development of Kaliningrad region for the long term", https://gov39.ru/working/ekonomy/strategy/

4. Federal Law No. 16-FZ dated January 10, 2006 "On the Special Economic Zone in Kaliningrad Region and on Amendments to Certain Legislative Acts of the Russian Federation"

5. Socio-economic situation of Kaliningrad Region for 2011-2020. Operational report/ Territorial body of the Federal State Statistics Service for Kaliningrad region, https://kaliningrad.gks.ru/

6. The main economic indicators of enterprises and organizations of industrial manufacture for January-December 2020. Statistical bulletin. Federal State Service of State Statistics/ Territorial body of the Federal Service of State Statistics for Kaliningrad region. Kaliningrad, 6 (2020)

7. Order of the State Customs Committee of the Russian Federation dated August 17, 1998 N 01-14/893 "On the application of customs regimes in Kaliningrad region" (together with the "Temporary procedure for the import of goods into the territory of Kaliningrad region and export of goods from the territory of Kaliningrad region") (Registered with the Ministry of Justice of the Russian Federation on October 08, 1998 N 1634)

8. Industry of Kaliningrad region. Statistical Collection. Federal State Service of State Statistics, Territorial body of the Federal Service of State Statistics for Kaliningrad region, Kaliningrad, 23 (2020) 
9. The Government of Kaliningrad Region, https://gov39.ru/

10. The Unified Federal Register of information on Bankruptcy. Debtor's card - legal entity. FM 555 LLC, https://bankrot.fedresurs.ru/

11. R. Chugumbaev, N. Chugumbaeva, Impact of the Covid-19 pandemic on the requirements for accounting and analytical support of business, International ScientificPractical Conference "Transformation of Corporate Governance Models under the New Economic Reality" Ekaterinburg, Russian Federation, November 20, 2020, SHS Web of Conferences, 89 (2020) 